\title{
Principles and Opportunities of the Study of Pictorial Heritage in the Practice of Choreographic Education
}

Tatiana V. Portnova* Russian State University named after A.N. Kosygin 1/33 Sadovnicheskaya Str., Moscow, 117997, Russia

Received 03.09.2018, received in revised form 03.12.2018, accepted 10.12.2018

The article is dedicated to an underdeveloped, but highly relevant aspect of work of museums, first of all the theatrical ones, namely keeping, studying and promoting the works associated with choreographic heritage. The objective of the article is to analyse the artistic and aesthetic features of museum exhibits dedicated to dance, their specific features in the context of methods of their study by undergraduates of choreographic faculties, as well as their attribution to artistic culture. An analytical approach to understanding of a theatrical exposition and a ballet exhibit in the context of modern conceptual methods of its study is chosen as a methodological basis. The artistic and aesthetic potential of material and visual exhibits related to the ballet theatre is revealed. All the figurative and metaphoric world of dance involved in a particular exhibition project is considered from the standpoint of the main carrier of a theatrical idea at the level of its perception by a master of a theatrical university as a potential researcher. The material is structured in accordance with the main concepts of the article analysing the aspects of studying choreographic heritage in museum collections, the methodology of studying museum items in theatrical expositions, the role of museum pedagogy in the prospects for studying choreographic heritage. The proposed aspects of considering the monuments of choreographic heritage in the museum environment brings this problem to a qualitatively new level of conceptuality, justifies the possibility of separating the theory of their study into an independent scientific field that integrates into the modern theatrical museum studies as a new direction of interdisciplinary knowledge and is developed by means of various humanities.

Keywords: choreographic heritage, theatrical collection, study methodology, museum exhibit.

Research area: art criticism.

Citation: Portnova, T.V. (2018). Principles and opportunities of the study of pictorial heritage in the practice of choreographic education. J. Sib. Fed. Univ. Humanit. soc. sci., 11(12), 2043-2055. DOI: 10.17516/1997-1370-0372.

(C) Siberian Federal University. All rights reserved

* Corresponding author E-mail address: infotatiana-p@mail.ru

This work is licensed under a Creative Commons Attribution-NonCommercial 4.0 International License (CC BY-NC 4.0). 


\section{Introduction}

Modern museum education is aimed at the enhancement of creative abilities of a person and creation of a multitier system of theatrical education. The problem of expansion of the cultural and educational space is solved by the use of various sources of culture and various kinds of knowledge. These include the usage of museums in the educational process of a future choreographer as a source of cultural values, repository of cultural standards and experience of mankind. "Museum can be called a unique result of interaction between culture and mind of a man" (Shiakhtina, 2011: 15). Various government programs aimed at the development of a cultural potential were reviewed during the study (State program of Moscow...; Lebedev, 1999: 50-60); Federal Targeted Program "Culture of Russia (2012-2018)". The survey attention field of the author includes various aspects of conceptualization of the place and functions of museum in culture and projects implemented conceptually (Loukaitou-Sideris \& Grodach, 2004: 49-71; Oestreicher, 1990: 4-5; Pitman, 1999: 1-31; Sidharta, 1994: 20-21; Schouvaloff, 1987: 144). Literature was analysed on the matters of museum activities (Dukelskii, 1986: 27-35; Kagan, 1994: 16-31; Nikishin, 1991: 7-15; Taran, 2005: 64-71). Among these sources, the most prominent were the works focused at the problem of museum education (Khodetskii, Kirsanova: 2002: 12-15; Umerkaeva, 2017: 35-37; Tišliar, 2017: 586-592; Palpacuer \& Christelle, 2018: 134-157; Burnham \& Kai-Kee, 2005: 65-76; Peleg \& Baram-Tsabari, 2016: 715-741). For instance, Vyshina regards museum education, as well as the direction of development of the system of additional education, revealing new functions of a museum teacher in a functional complex of school-museum-university (Vyshina, 1999: 202). S.M. Troianskaia refers to museum as a symbol of culture: "The mission of a museum as a symbol of culture and an educational institution is to play a major part in the formation of an integral person and development of its general cultural competence" (Troianskaia, 2007: 20-21). Museum education can be considered to be a factor of formation of social experience of a person: art enriches the life experience and museum facilitates the development of the above-said experience and skills. Research work of students and masters is not specified in the classification of the museum education forms made by museographer (Botiakova, 2006: 30). Speaking about the uniqueness of a theatrical museum, we would like to emphasize that the experience of personal contact with reality and actor culture of the past is exactly the main thing other institutes of civilization cannot offer.

Analysis of academic literature demonstrated the lack of developed standardized methods and recommendations for research work raising the level of general cultural 
and professional competence of masters. Museum is seen as one of the institutions designed for storing, collecting and interpreting objects. Based on the multicomponent structure of theatrical collections (Kolganova, 2003: 268; Kolganova, 2011: 300; Kaitandzhan, 2016: 100-109; Mintz, 1989: 446; Doroshenko, 2009: 6; Museum of theatre..., 1975; Bastrakova, 2008; Rodionov \& Djafarova, 2016; Rava, 1964; Weinberg, 2017; Preobrazhenskaia, 2002) we have developed indicators of competences of a researcher choreographer. Usage of specific opportunities and an educational potential of museums and museum education, active teaching methods, museum items and a museum environment, a figurative language of exhibition and works of theatrical art (Gibbons, 2013: 8-12). The author also studied new choreographic practices based on the interaction of a body, movement and other kinds of artistic creativity, since the museum environment represents an objective world that hides rich and unrevealed opportunities for ideas of new dance performances and their study (Sontag, 2018: 1-9; Shepard, 2018: 3-4; Rowell, 2016: 1163-1167; Gørrill, 2017: 236-238; Ehrenberg, 2015: 43-61).

Three major thematic groups are specified, forming the basis of their classification and representing the history of ballet theatre. Typology and variety of museum theatrical exhibitions demonstrating the substantial world of choreographic culture are emphasized (photographs, graphical and artistic portraits of ballet dancers, sculptures and figurines of the actors in roles, posters and broadsheets to the performances, theatrical masks, book editions and librettos for performances). This leads to creation of a subjectively new artistic product providing the expression of an exclusive value through the authenticity of museum exhibits. The subject field of exhibitions of specific theatre museums and possible aspects of their study are analysed.

The purpose of the research is to analyse the artistic and aesthetic features of museum exhibits dedicated to a dance, their specific features in the context of the methods of their study by masters of the choreography field, as well as their affiliation to the artistic culture.

\section{Research Methodology}

A methodological basis of the research is an analytical approach to understanding theatre exhibition and a ballet exhibit in the context of modern conceptual methods of its study. A culturological approach used in the article allows studying museum exhibits of a ballet theme as an integral aggregate of material and spiritual realias created in the course of historical development. Moreover, the methodological basis 
of the research included museology theories (a theory of documenting and a theory of museum communication) as the fundamental elements (Kolganova, 2013). A research aspect of the article was implemented through the applicable empirical research of capabilities of the museum and theatrical education for the development of general cultural and professional creative competence of students. We would like to note that the organization of research and project activities is the most effective at the undergraduate level, especially of the masters and $\mathrm{PhD}$ programs, as it stipulates possession of a certain level of experience in research searching and problematic methods of processing and analysis of obtained information.

\section{Aspects of studying the choreographic heritage in museum collections}

Museum items are studied using methods relevant to the branches specific to the museum: art history methods for art pieces are used; theatric history methods - for theatric materials; ballet history methods - for the narrower range of exhibits related to the ballet theatre. As museum historians study items not only as a source of knowledge, but also as a cultural value item and a source of emotions, attractive properties of an item are taken into account as well. The study of the museum items consists of three successive stages: attribution of objects, their classification and systematization, and then interpretation. Everything is different when talking about studying and researching museum items by novice researchers in the field of dance.

Theatre museums can be classified in three types: general profile museums in all their entirety; museums in theatres that are more focused and has permanent exhibitions related to the history of this theatre and its company; memorial museums dedicated to life and work of outstanding figures of theatrical arts (actors, directors). Exhibitions of the most famous theatre museums: A. Bakhrushin theatre museum (Moscow), Museum of theatrical and musical culture (Saint Petersburg), Paris theatre "Grand Opera", Milan theatre "La Scala", London theatre Covent garden, the New York "Metropolitan Opera", the Museum of the State Academic Bolshoi theatre in Moscow and Mariinsky theatre in Saint Petersburg based on the spectacular nature of theatrical art with its specifics. Such museums have quite big archives storing manuscripts, plans, and directors' design works for performances demonstrating the preparatory process.

Memorial museums are more chamber ones (the House Museum of K.S. Stanislavsky, the House Museum of M.N. Ermolova, the House Museum of G.S. Ulanova, etc.). As a rule, a memorial museum represents a theatrical person 
in the most diverse manifestations of his character, showing scenery where famous people lived and worked. Exhibits of these museums become priceless over time as a rare testament to the talent of these persons; visitors (theatre goers) will gladly learn these phenomena as these actors were for our culture. Collection of a theatre museum performs this important and noble task by all its imaginative informational material, all its clear structure.

As a rule, theatre museum has exhibits of a documental nature. Ballet iconography is one of the most important branches of theatre history: a discipline dealing with visual material reflecting various aspects of a dance performance. Iconographic sources can answer important questions related to history and a technique of dance, questions relevant to a ballet costume, questions characterizing the features of various dance schools, questions related to the relationship of a dance and culture in general. Hence, the concept of a personality of an actor, and the nature of the actor's dramatic path suggests the researcher at least two main interpretations. In one case one can speak, first and foremost, about the path of an actor or a director, as well as their position, credo, adopted moral, ideological and aesthetic principles; in the other case one can speak about development (evolution) of their work.

The most used classification as of now is the classification of types of museum exhibition based on the build-up method, i.e. the order of grouping and formation of exhibition materials: systematic, ensemble or themed, with each of them having a specific conceptual field for a researcher. Based on generalization of museumification of works of the choreographic material heritage, a concept was proposed describing formation of a creative approach to traditional and innovative methods of the build-up of exhibitions interpreted as a special cultural space designed for the future museum study.

A large selection of themes of creative works of masters of the choreographic profile lies in the source database, hence the museum's one and it needs to reflect their knowledge in a wide range of research problems, an ability to reflect upon and analyse them. The moment of contact with cultural values is experienced as a significant event for a young researcher who feels a sense of belonging, participation in a cultural life. It is the complicity that is not only through the event and empathy, but also through the promotion consisting of own creative, artistic and project activities. This is especially true for historical research. Given the dynamic nature of dance that will not be passed to descendants in its direct form, fixed images are the only authentic sources for the study. 


\section{Methods of study of museum items in theatrical exhibitions}

The most distinctive types of museum collections (including theatre museums) are typological, thematic or personal collections. The basis of any museum collection consists of items of the main fund. The main fund of a museum may only comprise authentic sources like material (personal belongings of actors), documental (ballet costumes, footprints, portrait images), written (letters and manuscript evidence), etc. Things like reproduction material (porcelain figurines), replicas (masks), reconstructions (copy of blueprints), stage layouts and replays reproducing the original comprise the auxiliary scientific fund. Along with the main and auxiliary scientific funds, temporary funds may be formed (items received from organizations or individuals for exhibitions, display, research, etc.). A researcher may come upon all this museum material and so the problem of selection and analysis of the existing information becomes exceptionally relevant.

Let us select three groups of research tasks corresponding to the structural components of their general cultural competence and directly related to the type and funds of a museum. Since the acquisition of funds for the museum must be focused depending on its profile, in turn, it determines the value of the museum item regarding its study. For instance, for a historical theatre museum the most valuable are the items of direct relevance to the history and theatrical culture of certain ages, including choreographical ones. Within the cultural historical method, theatre is interpreted as a product of social life and specific cultural and historical conditions. For a memorial theatrical museum the items related to the life and work of a particular individual are very important. A biographical method sets the relationship between the biography of a writer and features of their literary work. Biography and personality of a theatrical figure or an artist will be treated as a defining moment of work. Informational content of a source, its reliability (representativeness), visibility (attractiveness) should be taken into account when selecting items for the study. Museums existing in the theatres and choreographical educational institutions can be invaluable in providing unique materials and documents related to the history of their origin, to graduates of ballet schools and legends of the Russian ballet theatre, to performances staged at these theatres, to choreographers and artists. A historical and typological method will be the most wanted here, revealing the unity of similar, but unrelated phenomena with their similarity being the result of the coincidence of conditions of development. For example, choreographers and artists working together in the same company or those who graduated the same year, or performances that were set on the same stage in 
the choreographic reconstruction of the same or different directors. When conducting research in any theatre museum, a descriptive method will be the most appropriate, consistently interpreting the chosen material and systematizing it in accordance with the set research objective. In the analysis of an individual performance, it is preferred to use a structural method aiming to identify all the elements of the choreographic work and, at the same time, to recreate its model in general. An iconographic research method should to be used in the study of art materials and photographs that are usually stored in special sections in the cabinets, folders and shelves. They may help to learn how the ballet artists and choreographers of ages bygone looked like, as well as to imagine a style and manner of a dance performance. Finally, one of the main methods used in the research work is the iconological method that allows combining semiotics, origin, typology, symbolism and an artistic form, as well as revealing the specifics of each topic.

During the classification and systematization of museum items it is necessary to conduct a comparative analysis of their characteristic features with other items similar or close to the origin. To perform such a comparative analysis, one may use similar items from the museum, catalogues, indexes, etc. General and distinctive features that are inherent to a specific museum object are revealed during the works on classification and systematization. Then the information about the item should be summarized and structured by classifying and systematizing, which, in turn, allows more adequately interpreting the cultural, social, historical information inherent to a theatrical museum item.

Thus, a retrospective analysis of the data obtained during the study allowed identifying the target component of the theatre museum as an educational system, which can be divided into three groups of objectives: acquisition of skills for the ethic research in museum, communication with cultural heritage, acceptance of other cultures and a dialogue with them. This contributes to increasing the knowledge base in the field of choreography, stimulation of cognitive interests, and awareness of the belonging to modern culture.

\section{Museum education and opportunities of studying of choreographic heritage}

The empirical study of possibilities of museum education for the development of a general cultural competence through the implementation of experimental technologies comes to the front. It seems logical to use the unique educational opportunities of 
theatre museums as storages of cultural references and experience of mankind for the development of a common cultural competence of the future theatre figures. "Museum as a holistic educational system will work in the presence and the interaction of all structural and functional components subordinated to the overall objective of development and self-realization of a person, its belonging to the global flow of culture." (Botiakova, 2006: 48). G.V. Ganshina indicates the absence of a single methodological basis and practiceoriented technologies of joint socio-cultural activities of a university and a museum in terms of diversification of higher education (Ganshina, 2016: 196-209). Now and in the future museums the global visualization of culture will be included in the general educational process of the period of digitization. According to B. Stoliarov, museums will become a school of "...visual and spatial thinking that attaches a person to the surrounding world through the monuments of culture and art; a space that accumulates an aesthetic experience of mankind and provides an individual with the opportunity of self-identification; a filter of quality in man's relation to life and the environment in its substantive, philosophical and ethical sense" (Stoliarov, 2001: 177-182). The expansion of cultural and educational space must occur through the inclusion of museums in the educational process at universities (Kolganova, 2013; Zhukov, 2001; Conn, 2016: 309-323). However, even such traditional museum activities as guided tours, didactic and creative exhibitions, and museum electives are not always used these days. "The first historically established forms of museum and educational activities are lectures, guided tours and consultations, in which the museum item (museum exhibition) are an integral part of the museum and educational process" (Galkina, 2012: 144-158). Three main forms of educational process: lessons in a museum exhibition, classroom and practical lessons should be supplemented by the application of a systematic approach with target definition, structuring of content, choice of methods, means and forms presented in the schematic design of the experimental technology. Appeal to cultural standards is expedient in practical tasks, including creative design already at the stage of undergraduate courses of a bachelor's degree and final thesis papers. Already on this initial level, abilities of emotional perception, dialogic interaction in the process of communication with cultural values through the museum communication are formed. The educationally expedient use of the museum environment contributes to immersion in a certain era, reliving historical situations, updating of associative links, coexistence and participation, belonging to the cultural stream. The multi-sensory impact was especially effective, when visual perception was reinforced by the guide speech, music, tactile and olfactory sensations and application of interactive exhibits. Experimental 
work with students at the premises of universities is relevant at the masters' stage. Museums can become the main bridge between the first and the advanced research level of work on a dissertation project, between modernity and the past, between a man and the cultural heritage.

\section{Conclusion}

Thus, considering the foregoing, iconographic, decorative and other material stored in collections and displayed in the exhibitions of theatre, museums can be an important source for the study of choreographic heritage. Theoretically explaining the meaning and purpose of a museum not only as a source of storage of exhibits and desobjectivation of cultural values, but also as means for the development of research abilities, we identified and used the educational potential of a museum and museum education. Unfortunately, the distinctive feature of modern museums from the traditional ones is the change of priorities, when the focus is set more on the entertainment aspect and working with mass visitors without reference to their education level. However, the analysis of existing creative works of students and research papers by masters also allows making a conclusion about the positive impact of experimental education on the implementation of abilities determining the development of the general cultural competence with the means of museum theatrical education. The innovation processes going in the art have an impact on the methods of their study as well (Heilbrun, 1993: 89-98). The methodology of the study of museum items with a theatre context presented in this article, as well as technology of development of the general cultural and professional competence can be used by university professors and museum teachers in performing their project and educational activity and is recommended to students who undertook highly specialized courses and masters who are preparing their research studies on choreography. The research results can be used when leading highly specialized courses in the system of training and retraining of teachers for various educational systems.

\section{References}

Bastrakova, L.P. (2008). Museum of theatrical and musical art: a chronicle of the century, 1908-2008. Saint Petersburg, Art Deco, 246 p.

Botiakova, O.A. (2006). Ethnographic museum in the context of education and culture of Russia: a dissertation abstract. Saint Petersburg, Saint Petersburg State University, $30 \mathrm{p}$. 
Burnham, R. \& Kai-Kee, E. (2005). The Art of Teaching in the Museum. In Journal of Aesthetic Education, 39 (1), 65-76.

Conn, S. (2016). Do Universities Need Museums/Do Museums Need Universities? In The Antioch Review, 74 (2), 309-323.

Doroshenko, P.V. (2009). Memorial apartment of G.S. Ulanova (Moscow). In Branch of A.A. Bakhrushin State Central Theatre Museum: informational publication. Moscow, $16 \mathrm{p}$.

Dukelskii, V.Iu. (1986). Terminological problems of the theory of museum item. In Terminological problems of museology. Moscow, 27-35.

Ehrenberg, S. (2015). A Kinesthetic Mode of Attention in Contemporary Dance Practice. In Dance Research Journal, 47 (2), 43-61.

Federal Targeted Program “Culture of Russia (2012-2018)”. Available at: http:// fcpkultura.ru (accessed 31 August 2018).

Galkina, T.V. (2012). Basic principles of classification of museum education forms in Russian museums. In Matters of museology, (4), 144-153.

Ganshina, G.V., Gribkova, G.I. \& Umerkaeva, S.Sh. (2016). Diversification of higher education in the conditions of socio-cultural interaction of university and museum. In Social and cultural partnership: university-museum-library in the conditions of innovative development: a collective monograph. Moscow, UTs Perspektiva, 196-209.

Gibbons, W. (2013). Building the Operatic Museum: Eighteenth-Century Opera in Fin-de-Siècle Paris. Boydell \& Brewer, University of Rochester Press, 90 p.

Gørrill, H. (2018). Drawing difference: connections between gender and drawing. In Journal of Visual Art Practice, 17 (2-3), 236-238.

Heilbrun, J. (1993). Innovation in art, innovation in technology, and the future of the high arts. In Journal of Cultural Economics, 17 (1), 89-98.

Kagan, M.S. (1994). Museum in the system of culture. In Matters of art history, 4, 16-31.

Kaitandzhan, M.G. (2016). Theatre museum of Moscow as potential partners of universities in preparation of students to dramatized forms of cultural and leisure activities. In Social and cultural partnership: university-museum-library in the conditions of innovative development: a collective monograph. Moscow, UTs Perspektiva, 100-109.

Khodetskii, V.G. \& Kirsanova, E.L. (2002). University museum and its educational role. In Museum and student: a compilation of research papers. Syktyvkar, 12-15. 
Kolganova, A.A. (2003). History of theater libraries and collections: The fifth academic readings. Theatrical book between the past and the future: lectures, papers. Moscow, Fair-Press, 268 p.

Kolganova, A.A. (2011). Russian state art library. In History of theatre in the archival and book collections: The ninth academic readings. Theatrical book between the past and the future: lectures, papers. Moscow, Tri Kvadrata, $300 \mathrm{p}$.

Kolganova, A.A. (2013). Russian state art library, In Documenting the theatrical heritage: an international science conference: On the $90^{\text {th }}$ anniversary of the Russian state art library: lectures, papers, publications. Moscow, Novoe Izdatelstvo, $424 \mathrm{p}$.

Lebedev, O.E. (1999). Expansion of the educational space. Educational programs. Saint Petersburg, 50-60.

Loukaitou-Sideris, A. \& Grodach, C. (2004). Celebrating the "Other": A Study of the Mission, Scope, and Roles of Ethnic Museums in Los Angeles. In The Public Historian, 26 (4), 49-71.

Mintz, N.V. (1989). Theatre collections of France. Moscow, Iskusstvo, 446 p.

Museum of theatre and music (Tallinn): Guide. (1975). Tallin, Ministry of culture of the ESSR, $22 \mathrm{p}$.

Nikishin, N.A. (1991). "Museum language" as a universal modeling system of museum activity. In Problems of cultural communication in museum activity. Moscow, Muzei mira, 7-15.

Oestreicher, L. (1990). Museum Theater: Coming of Age. In The Journal of Museum Education, 15 (2), 4-5.

Palpacuer, L. \& Christelle, J. (2018). Multiliteracies in Action at the Art Museum. In L2 Journal, 10 (2), 134-157.

Peleg, R. \& Baram-Tsabari, A. (2016). Understanding Producers' Intentions and Viewers' Learning Outcomes in a Science Museum Theatre Play on Evolution. In Research in Science Education, 46 (5), 715-741.

Pitman, B. (1999). Muses, Museums, and Memories. In Daedalus, 128 (3), 1-31.

Preobrazhenskaia, I.S. (2002). A.A. Bakhrushin State Central Theatre Museum (Moscow): guide to the manuscript fund of the A.A. Bakhrushin State Central Theatre Museum. Moscow, A.A. Bakhrushin State Central Theatre Museum, 415 p.

Rava, E. (1964). La Scala Theatre (Milan). Catalogue of the exhibition of theatrical paintings. Russian translation by Ch. Gianluigi. Moscow, $106 \mathrm{p}$.

Rodionov, D.V. \& Djafarova, S.G. (2016). Breakthrough. Russian theatre and decorative art 1870-1930: catalogue of exhibition in 2 parts. Moscow, A.A. Bakhrushin State Central Theatre Museum, 399 p. 
Rowell, C. (2016). Two Galleries, Engaging Art, Great Talents, and Challenging Minds: The Howard University Gallery of Art, the Little Paris Group, and the BarnettAden Gallery. In Callaloo, 39 (5), 1163-1167.

Sam, S. (2018). Experimental Theatre Then and Now. In Journal of Performance and Art, 40 (1: T118), 3-4.

Schouvaloff, A. (1987). The Theatre museum: Victoria and Albert museum. London, Scala books, $144 \mathrm{p}$.

Shlyakhtina, L.M. (2011). Modern museum: ideas and realities. In Matters of museology, 2 (4), 14-19.

Sidharta, A. (1994). Visual Elements of Exhibitions. In The Journal of Museum Education, 19 (1), 20-21.

Sontag, S. (2018). Art and Consciousness. In Journal of Performance and Art, 27 (2: 80), 1-9.

State program of Moscow city "Culture of Moscow for 2012-2018”. Available at: http://kultura.mos.ru (accessed 31 August 2018).

Stoliarov, B.A. (2001). Museum education: the past and the present. In Narodnoe Obrazovanie, (5), 177-182.

Taran, A.V. (2005). University museums of Russia: the past, the present and the future. In Cultural observatory: the observer magazine, (2), 64-71.

Tišliar, P. (2017). The Development of Informal Learning and Museum Pedagogy in Museums. In European Journal of Contemporary Education, 6 (3), 586-592.

Troianskaia, S.L. (2007). Museum education and its educational opportunities in the development of general cultural competence. Izhevsk, Assotsiatsiya "Nauchnaya kniga", $139 \mathrm{p}$.

Umerkaeva, S.Sh. (2017). Museum and university: relevant problems of sociocultural interaction. In Interactive science, 6 (16), 35-37.

Vyshina, G.V. (1999). Museum education as the direction of development of system of additional education: dissertation. Lipetsk, $202 \mathrm{p}$.

Weinberg, N.I. (2017). Theatre museum: masterpieces of the collection: guide. Saint Petersburg, Museum of theatrical and musical art, $36 \mathrm{p}$.

Zhukov, R.F. (2001). Ways of development of active methods of education in the university. In Technology of acmeological methods of education: scientific works. Saint Petersburg, Spbgieu, 160 p. 


\section{Принципы и возможности исследования}

художественного наследия

в практике хореографического образования

Т.В. Портнова

Российский государственный университет

им. А.Н. Косыгина

Россия, 117997, Москва, ул. Садовническая, 33, к. 1

Статья посвящена недостаточно развитым, но весьма актуальным аспектам работы музеев, прежде всего театральным, а именно сохранению, изучению и продвижению произведений, связанных с хореографическим наследием. Цель работы состоит в том, чтобы проанализировать художественные и эстетические особенности музейных экспонатов, посвященных таниу, специфические особенности в контексте методов их изучения студентами хореографических факультетов, а также их атрибуцию художественной культуры. В качестве методологической основы выбирается аналитический подход к пониманию театральной и балетной экспозиций в контексте современных концептуальных методов их изучения. Выявлен художественный и эстетический потенциал материальных и визуальных экспонатов, связанных с театром балета. Весь образный и метафорический мир танца, участвующий в конкретном выставочном проекте, рассматривается с точки зрения главного носителя театральной идеи на уровне его восприятия магистром театрального университета как потенциильного исследователя. Материал структурирован в соответствии с основной концепцией статьи, что позволяет проанализировать аспекты изучения хореографического наследия в музейных собраниях, методологию изучения музейных предметов в театральных экспозициях, роль музейной педагогики в перспективах изучения хореографического наследия. Предлагаемые аспекты рассмотрения памятников хореографического наследия в музейной среде выносят эту проблему на качественно новый уровень концептуальности, оправдывают возможность отделения теории их изучения от самостоятельной научной области, которая интегрируется в современные театральные музеи как новое направление междисциплинарных знаний и рассматривается в рамках различных гуманитарных наук.

Ключевые слова: хореографическое наследие, театральная коллекция, методика обучения, музейная экспозищия.

Научная специальность: 17.00.00-искусствоведение. 